\title{
POSSIBILIDADES DO EQUÍVOCO: \\ A TRADUÇÃO DO PASSADO NO TEXTO AUTOBIOGRÁFICO
}

\author{
Leandro De Bona Dias* \\ Mário Abel Bressan Júnior **
}

RESUMO: A partir do conceito de equivocidade controlada (VIVEIROS DE CASTRO, 2018), o artigo apresenta a tese de que na escrita literária autobiográfica ocorre uma tradução via equívoco de memória. Há, portanto, o que ocorreu, o que é enunciado sobre isso, e o resultado é uma terceira coisa que surge da diferença entre esses dois movimentos: o equívoco de memória. Partindo desse pressuposto e compreendendo a literatura e a ficção como elementos que compõem a realidade (CANDIDO, 2011, 2006; HALL, 2003, BAKHTIN, 2011), propõe-se uma discussão acerca do entrelaçamento entre a linguagem literária e a memória (LE BRETON, 2009; HALBWACHS, 1990) a fim de apresentar as bases para o desenvolvimento do equívoco de memória, conceito ainda em construção.

PALAVRAS-CHAVE: Autobiografia; Literatura; Memória.

\section{Inquietações}

A gestação das inquietações do presente artigo tem como origem o escritor argentino Jorge Luis Borges, mais especificamente dois de seus contos: Pierre Menard, autor de Quixote e Funes, o memorioso. Neste Irineo Funes é um uruguaio que aos dezenove anos, após cair de um cavalo, fica aleijado, mas percebe, ao recobrar a consciência, que sua memória se tornara prodigiosa, sendo capaz de lembrar de cada detalhe de tudo o que seus olhos veem. "Recordo-o (não tenho o direito de pronunciar esse verbo sagrado, somente um homem na terra teve direito e esse homem morreu) [...]” (BORGES, 1976, p. 53), diz o narrador que nos relata a história. Interessante notar o uso do verbo recordar, de origem latina ${ }^{1}$ e que significa trazer de volta ao coração, etimologia próxima da de decorar, saber

\footnotetext{
${ }^{*}$ Mestre em Educação pela Universidade do Extremo Sul Catarinense (Unesc). Doutorando em Ciências da Linguagem Universidade do Sul de Santa Catarina (Unisul).

** Doutor em Comunicação Social pela Pontifícia Universidade Católica do Rio Grande do Sul (Puc-RS). Professor do Programa de Pós-Graduação em Ciências da Linguagem da Universidade do Sul de Santa Catarina (Unisul).

${ }^{1}$ Disponível em: https://hridiomas.com.br/origem-da-palavra-recordar/. Acesso em 29 jul. 2020.
} 
de cor, ou seja, saber de coração. Nesse sentido, o coração é compreendido como órgão ligado à memória ou à capacidade de lembrar. É possível depreender daí o papel da afetividade como condição importante para a recordação. A esse respeito, o francês David Le Breton afirma que

Um homem que pensa é sempre um homem afetado, alguém que reúne o fio de sua memória impregnada de certo olhar sobre o mundo e sobre os outros. [...] As emoções traduzem a ressonância afetiva do acontecimento de maneira compreensível aos olhos dos outros. Sua proveniência não é exclusivamente individual: ela é uma consequência íntima, ocorrida na primeira pessoa, de um aprendizado social, em primeiro lugar, e de uma identificação com os outros, em segundo lugar. (2009, p. 116-117)

Temos, portanto, um narrador afetado pela memória de seu encontro com Funes. A ressonância de que fala Le Breton pode ser constatada na quantidade de vezes, cinco ao todo, em que a palavra recordar é utilizada nesse mesmo primeiro parágrafo. Estamos, portanto, diante de um narrador que rememora um acontecimento e de uma personagem que é descrita como dotada de uma memória infalível. Já no final do texto, Funes, que vivia num quarto às escuras, é descrito como "[...] o solitário e lúcido espectador de um mundo multiforme, instantâneo e quase intoleravelmente exato. [...]” (BORGES, 1976, p. 56). A agonia de Funes resulta, portanto, não da capacidade de rememorar tudo de modo preciso, mas do fato de não ser capaz de esquecer. O narrador do conto dirá "Pensar é esquecer [...]" (BORGES, 1976, p. 56), e esse é o ponto. É preciso esquecer para significar, seja para silenciar, seja para “[...] escovar a história a contrapelo", nos termos de Walter Benjamin (1978, p. 225).

Esta breve análise de parte do conto serve para mostrar como a memória ocupa um lugar de destaque na narrativa, o que é acentuado pela ambígua condição de Funes, condenado a jamais esquecer tudo o que vê. É possível enxergar nessa personagem de Borges a utopia da memória total, descrita por Paul Ricoeur (2007, p. 40) como estando vinculada à ambição "[...] de ser fiel ao passado". Contudo, pode-se perceber na descrição de Funes um tom de lamento que acompanha essa incapacidade de esquecer: “"Minha memória, senhor, é como despejadouro de lixos"' (BORGES, 1976, p. 56). Seria a memória total uma 
dádiva ou um castigo? $\mathrm{Na}$ literatura, a ilusão de um relato fiel a um universo pretérito, mesmo que ficcional, seria possível?

Já no conto Pierre Menard, autor de Quixote temos descrição feita pelo narrador a respeito do empreendimento inacabado de um escritor francês que tinha como ambição: “[...] compor [não] outro Quixote - o que é fácil - mas o Quixote” (BORGES, 1976, p. 20). Dessa obra inconclusa e subterrânea, nas palavras do próprio narrador/biógrafo de Menard, restariam apenas três fragmentos, assim apresentados:

Constitui uma revelação cotejar o Dom Quixote de Menard com o de Cervantes. Este, por exemplo, escreveu (Dom Quixote, primeira parte, nono capítulo):

....a verdade, cuja mãe é a história, êmula do tempo, depósito das ações, testemunha do passado, exemplo e aviso do presente, advertência do futuro.

[...] Menard, em compensação, escreve:

..... verdade, cuja mãe é a história, êmula do tempo, depósito das ações, testemunha do passado, exemplo e aviso do presente, advertência do futuro.

[...] é vívido o contraste dos estilos. O estilo arcaizante de Menard - no fundo estrangeiro - padece de alguma afetação. Não assim o do precursor, que emprega com desenvoltura o espanhol corrente de sua época. (BORGES, 1976, p. 23)

Não há erro de digitação, são duas versões de Quixote: a primeira escrita por um espanhol no século XVII, a segunda por um francês no início do século XX. O texto, palavra por palavra, é o mesmo e, ao mesmo tempo, é outro. Qual seria essa relação entre um "mesmo" texto lido em tempos e espaços diferentes? Literatura, memória, permanência, esquecimento são alguns temas que me surgem repetidamente após a leitura de Borges. Em outras palavras, se a nossa memória é afetada pelas nossas experiências, se o que lembramos nunca poderá ser retomado como antes, mesmo numa gravação, visto que nós que àquilo assistimos já não seremos os mesmos, se nisso tudo a linguagem desempenha um papel fundamental, qual seriam então as implicações dessas peculiaridades relativas à memória nas narrativas literárias autobiográficas? Quais os efeitos dos modos de se narrar o passado? São essas algumas indagações que me provocam na escrita deste texto. 


\section{Os estudos sobre memória e literatura}

Diante das questões postas na seção anterior, dispus-me a estudar as relações entre memória e literatura e a fazer um levantamento acerca dos trabalhos acadêmicos já realizados sobre os temas. Comecemos pelos dados. Conforme apontam Fábio Akcelrud Durão e Tauan Tinti no texto Sobre a memória na sociedade da imagem:

[...] em não mais de 25 anos, a memória tornou-se o principal tópico de estudo de literatura no Brasil. [...] no primeiro semestre de 2018, "memória" é o quarto termo mais frequente nas linhas de pesquisa dos 105 programas de pós-graduação que contemplam a pesquisa em literatura, estando presente em 28 deles. (2019, p. 263)

A constatação dos autores os leva a uma análise do modo como as pesquisas sobre memória são desenvolvidas, o que os faz chegar a três formas de agrupamento: 1) a memória patrimoniadora: aquela que se dedica a estudar um item como marca testemunhal de um acontecimento; 2) a memória identitária: estudos que se dedicam a buscar as marcas de construção de identidade de determinados grupos; e, por fim, 3) a memória catastrofal: categoria que agrupa textos que contêm marcas de eventos como o Holocausto. De qualquer maneira, o diagnóstico sobre esses estudos, ainda que realizado no texto dos autores de forma breve, é o de que

[...] neles, a concepção de forma literária tende a se restringir - e cada vez mais - ao conjunto de procedimentos característicos da rememoração, ou da relação entre testemunho e verdade histórica. Melhor dizendo, o aspecto especificamente literário da ideia de forma cede terreno e pode mesmo ser substituído pela especificidade da lógica memorialista. (DURÃO; TINTI, 2019, p. 265)

A partir dessa fala, realizei uma pequena incursão pelo Banco de Teses e Dissertações da Capes selecionando alguns estudos sobre memória e literatura a fim de verificar a pertinência ou não do argumento defendido na citação acima. Vejamos alguns deles.

Na dissertação intitulada Autobiografia e memória de Gabriel García Márquez: ficcionalização de si, a autora Karine Carvalheiro se debruça sobre a obra do autor colombiano e nos diz que 
As obras confluem para revelar a memória pessoal fundida à memória coletiva, memórias da infância e da casa, da atividade de escritor e o jornalista impedido de escrever, em função da repressão política na América Latina no contexto das ditaduras. (2017, p. 9)

Aqui, a pesquisadora compreende a escrita do autor como sendo híbrida, no entanto busca na realidade alguns apontamentos sobre a sua obra, como que em um cotejamento entre o escrito e a experiência vivida por García Márquez. Por sua vez, Denise Noronha Lima na sua tese O espaço da memória em José Saramago: literatura e autobiografia, defendida em 2017, reconhece a relação entre vida e obra do autor, e parte de uma análise que busca também comparar, por meio de entrevistas e de relatos, o autor real com a personagem Saramago em seus textos autobiográficos. Em outra dissertação disponível para consulta, Literatura, história e memória: uma leitura da poesia de Mario Benedetti, Maria de Nazaré Fonseca Corrêa conclui que

[...] a poesia benedettiana ratifica o poder da escrita na preservação da memória como fonte da história. Pela recordação se mantêm vivos e presentes os crimes cometidos pela ditadura, com o intuito de buscar uma reparação para os abusos cometidos e também evitar a repetição dos atos de barbáries. (2013, p. 173)

Não irei citar aqui todos os trabalhos que pude consultar, pois a busca que frz pelo termo memória e literatura retornou 51 resultados, sendo o mais antigo de 2003 e o mais recente de 2018. De modo geral, essa pequena amostra que descrevo trabalha justamente com a perspectiva apontada por Durão e Tinti (2019), ou seja, as pesquisas pretendem relacionar, cotejar, buscar vestígios das experiências vividas pelos autores, seja nos textos tidos como autobiográficos, caso de Saramago e García Márquez, seja na poesia de Benedetti, destacada pela autora como elemento de preservação histórica. A análise que faço de maneira nenhuma invalida as pesquisas realizadas a partir desse ponto de vista teórico, contudo uma questão, já citada anteriormente, segue pertinente: seria possível realizar uma comparação entre o escrito e o vivido, como sugerem os estudos dos quais os três trabalhos acima são exemplos? Deixemos a pergunta suspensa e sigamos. 
Ainda sobre o levantamento que realizei, cabe destacar a dissertação de Mariana Luz Pessoa de Barros, defendida em 2006 e intitulada $A$ arquitetura das memórias: um estudo do tempo no discurso autobiográfico. Nela, a autora analisa as obras Baú de ossos, de Pedro Nava, e Infância, de Graciliano Ramos, sobre o aspecto do tempo enquanto forma. No trabalho é possível perceber um tratamento diferente em relação ao texto literário. Aqui não mais se investigará a relação entre o que está escrito e o que o autor viveu, mas, sim, as relações intratextuais no que diz respeito ao modo como essas memórias são narradas, como no trecho abaixo em que o narrador de Infância é analisado:

A impossibilidade de recuperar a totalidade do passado é, então uma característica importante da memória do narrador. Sobre um antigo verão que parece ter modificado muito sua vida, afirma: "O meu verão é incompleto. O que me deixou foi a lembrança de importantes modificações nas pessoas" (GR, p. 28). O fragmento é assim a forma encontrada para mostrar o modo de funcionamento da memória, que é incompleta. (BARROS, 2006, p. 194)

Como se vê, o que interessa para a pesquisadora é o modo como discursivamente se constrói a narração das memória e não, efetivamente, sua verdade histórica. Operação muito diversa da realizada por Rute Augusto Possebom em sua pesquisa de dissertação Infância, de Graciliano Ramos: memória ou autobiografia, de 2011, como fica explicitado nos resultados a que chega a autora:

Se por um lado aspectos da vida de Graciliano estão presentes na narrativa, por outro, a linguagem poética institui a máscara e o fingimento. A dominância do caráter memorialístico permite, portanto, a apreensão de traços do real e, ao mesmo tempo, transmuta o passado do menino, caracterizando-o como protagonista de uma narrativa também ficcional. (POSSEBOM, 2011, p. 7)

Embora considere ambas as leituras, a ficcional e a, digamos, testemunhal, a pesquisa de Possebom ainda permanece presa ao que chama de "traços do real" na obra.

Tendo como base o levantamento realizado, assumo uma posição que se assemelha à de Barros (2006) e busco analisar a memória não como um elemento que, no texto literário, sirva como um espelho, ainda que refratado e com pedaços faltantes, da realidade, 
mas antes como um recurso narrativo. Para tanto, agora é preciso que eu explique de que modo tomarei aqui os termos memória e literatura.

\section{Memória e literatura}

Tomando como referência as críticas feitas acima, coloco-me neste artigo contra uma concepção de memória ligada à possibilidade de retomar um fato passado. Pare esmiuçar essa ideia recorro a Platão no seu diálogo Fedro. No texto, Sócrates conta a Fedro a história de um Deus egípcio chamado Thoth, que, havendo descoberto a escrita, foi apresentá-la a Tamuz, então rei do Egito, e assim lhe disse:

"Esta arte, caro rei, tornará os egípcios mais sábios e lhes fortalecerá a memória; portanto, com a escrita inventei um grande auxiliar para a memória e a sabedoria". Responde Tamuz: “Grande artista Thoth! Não é a mesma coisa inventar uma arte e julgar da utilidade ou prejuízo que advirá aos que a exercerem. Tu, como pai da escrita, espera dela com o teu entusiasmo precisamente o contrário do que ela pode fazer. Tal coisa tornará os homens esquecidos, pois deixarão de cultivar a memória; confiando apenas nos livros escritos, só se lembrarão de um assunto exteriormente e por meio de sinais, e não em si mesmos. Logo, tu não inventaste um auxiliar para a memória, mas apenas para a recordação”. (PLATÃO, s/d, p. 178-179)

Como se vê, a escrita, do ponto de vista de Thoth, é interessantemente descrita como sendo um remédio para a recordação. A fala de Tamuz compreende a invenção a ele apresentada como não sendo capaz de conter a experiência ou de retomar um fato vivido, ideia que se baseia, ainda, numa concepção de memória como possibilidade de evocar o passado. Recordar é aquilo de que ela é capaz, e o ato de recordar, portanto, não conteria em si a propriedade da experiência. Como bem observa Evando Nascimento (1999, p. 106): "[...] a teoria logocêntrica da linguagem no Fedro se estabelece a partir da oposição entre o vivo e o morto, a memória e a recordação, o modelo e a imagem, a presença e a ausência". Está aí descrita uma oposição entre uma forma viva, real de saber, de conhecer, e uma forma enganadora, a escrita.

O mesmo autor, argumentando por meio da leitura de Jacques Derrida, diz que “Quanto à escrita, ela é inaceitável porque 'repete sem saber' a realidade do ente-presente 
que é o lógos, ou seja, ela nada tem a ver com a referência à verdade como desvelamento da presença plena.” (NASCIMENTO, 1999, p. 107). Partindo dessa fala, o argumento contra o qual me oponho é o de que a escrita, especificamente a literária no que diz respeito aos textos que evocam memórias, deva ser subjugada ao que foi realmente vivido. Dito isso, é preciso registrar que a posição que tomo não se trata de um retorno a qualquer espécie de psicologismo; a realidade, a carne e o osso, existem. O que afirmo é que, ao tratar aqui das memórias no texto literário, não irei procurar submetê-las a uma comparação com aquilo que foi vivido pelo seu autor real, pela pessoa que escreveu tais memórias.

Ainda sobre o dualismo entre realidade e ficção, que se assemelha a outro, entre idealismo e realismo, Henri Bergson (1999), na introdução de seu livro Matéria e Memória, afirma que não podemos reduzir o mundo nem à matéria em si, às coisas em si mesmas, nem à representação, ao modo como as percebemos. Desse modo, seu estudo se dedica a investigar qual a relação entre essas duas coisas, o corpo, que percebe, e a matéria, que é percebida. A certa altura ele escreve:

[...] enquanto recobre com uma camada de lembranças um fundo de percepção imediata, e também enquanto ela contrai uma multiplicidade de momentos, [a memória] constitui a principal contribuição da consciência individual na percepção, o lado subjetivo de nosso conhecimento das coisas [...] (BERGSON, 1999, p. 31)

A memória aparece aqui como um dispositivo indispensável à percepção, posto que realiza uma operação delicada entre a consciência individual de um objeto e sua materialidade no mundo. Colocando de outra forma, e adicionado à discussão o ponto de vista de Stuart Hall (2003), digo que é a linguagem, e portanto também a memória que por meio dela é construída, o modo pelo qual fazemos sentido das coisas no mundo, uma vez que “[a]s relações sociais têm que ser 'representadas na fala e na linguagem' para adquirir significado" (HALL, 2003, p. 161).

É importante pontuar que a adoção dessa postura não nos deve jogar a um perspectivismo último, ou seja, a percepção do objeto, embora o componha, não é capaz de, por si, modificá-lo. Assim, o fato de minha percepção não ser capaz de compreender a presença de uma porta de vidro não impedirá que eu me choque contra ela ao tentar 
ultrapassá-la. De qualquer maneira, dirigindo-me agora ao que entendo por ficção, utilizo aqui conhecido trecho do texto $O$ direito à literatura, de Antonio Candido, que, ao tocar nesse assunto, assim escreve:

Não há povo e não há homem que possa viver sem ela, isto é, sem a possibilidade de entrar em contato com alguma espécie de fabulação. Assim como todos sonham todas as noites, ninguém é capaz de passar vinte e quatro horas do dia sem alguns momentos de entrega ao universo fabulado. [...] Ela se manifesta desde o devaneio amoroso ou econômico no ônibus até a atenção fixada na novela de televisão ou na leitura seguida de um romance. (2011, p. 176-177)

Dessa maneira, a ficção é compreendida como um componente da realidade, tendo em vista que esta é percebida também de modo ficcional e esse modo de perceber nos impele a agir de determinada maneira porque, recorro novamente a Candido, a arte, assim como a memória e a percepção,

[...] é social nos dois sentidos: depende da ação de fatores do meio, que se exprimem na obra [ou consciência neste caso] em graus diversos de sublimação; e produz sobre os indivíduos um efeito prático, modificando a sua conduta e concepção do mundo, ou reforçando neles o sentimento dos valores sociais. (2006, p. 30)

Por isso, entendo o termo memória não apenas como uma capacidade de retomar algo que fora experienciado por um indivíduo em sua corporeidade, mas, sim, nos termos de Nascimento (1999), como uma escrita potencialmente parricida, ou seja, que, à revelia do pai, que a havia criado como solução para apreender o passado, pode agora matá-lo, traí-lo, porque não possui um compromisso com ele. Portanto, embora os ideais da figura paterna ainda assombrem a escrita da memória, seu vínculo com tais ideias não deve mais ser compreendido como uma espécie de repetição platônica de algo exterior. É a escrita literária dessa memória, ela mesma, o que me interessa. Por isso, falemos agora um pouco mais sobreo gênero autobiográfico.

\section{Memória e literatura}

O próprio termo que intitula esta seção já foi alvo de diversas pesquisas acadêmicas que tentaram responder o que seria, ou como se configuraria, afinal, o texto autobiográfico. 
Não pretendo, obviamente, responder a essa pergunta, mas é preciso discutir a questão. Para tanto, trago a perspectiva de Leonor Arfuch, que em seu livro O espaço biográfico: dilemas da subjetividade contemporânea realiza um riquíssimo estudo sobre o tema. A autora evoca Philippe Lejeune para falar do "pacto autobiográfico", conceito por ele desenvolvido e, segundo o qual, o leitor de uma obra que se proclama autobiográfica, assina uma espécie de contrato no qual concorda em aceitar a identidade entre autor (pessoa) e narrador do texto. Arfuch se questiona a respeito dessa possível identidade: "Até que ponto pode se falar de 'identidade' entre autor, narrador e personagem? Qual é a referencialidade compartilhada, supostamente, tanto pela autobiografia quanto pela biografia?” (ARFUCH, 2010, p. 53). Outro autor citado pela pesquisadora é Jean Starobinski, que chama a atenção para um problema de autorreferência no momento da escrita, tendo em vista que o autor que escreve o faz em seu eu atual, e é esse eu que irá contar os acontecimentos passados, por isso “[...] não somente o relato 'retrospectivo' será indecidível em termos de sua verdade referencial, mas, além disso, resultará de uma dupla divergência [temporal e identitária]" (ARFUCH, 2010, p. 54). Diante desses impasses sobre o gênero, a autora recorre a Mikhail Bakhtin para afirmar com ele que "[...] não há identidade possível entre autor e personagem, nem, mesmo na autobiografia, porque não existe coincidência entre a experiência vivenciada e a 'totalidade artística"' (ARFUCH, 2010, p. 55). Indo até a Estética da criação verbal, lemos:

[...] o autor é elemento do todo artístico e como tal não pode coincidir dentro desse todo com a personagem, outro elemento seu. A coincidência pessoal "na vida" da pessoa de quem se fala com a pessoa que fala não elimina a diferença entre esses elementos no interior do todo artístico. (BAKHTIN, 2011, p. 319)

Mesmo sem buscar uma solução para o embate entre a pessoa que escreve e aquele que narra, a posição de Bakhtin será por mim adotada, tendo em vista que ela coaduna com a conceituação que proponho a respeito de uma memória parricida, pois, uma vez que se abandona, conceitualmente, a referência a um autor real, de carne e osso, é possível concentrar a análise da obra literária em termos de uma memória do narrador, o que difere, 
está claro, de uma busca pelos acontecimentos vividos fora do texto por aquele que se proclama seu autor autoreferencial.

É oportuno, ainda sobre o tema, citar a ideia de que, segundo Anatol Rosenfeld (2014, p. 16), na narração “[o] pretérito, apesar de em certos casos ter o cunho fictício de 'era uma vez', tem em geral mais força 'realizadora' e 'individual' do que a voz do presente”. O mesmo autor exemplifica a ideia dizendo que o enunciado $O$ elefante pesa no mínimo uma tonelada cria uma interpretação mais geral, enquanto a frase $O$ elefante pesava no minimo uma tonelada parece se reportar a um animal em determinado momento da existência. Seria, portanto, a utilização de tal recurso narrativo um modo de fazer com o leitor comungue de uma verossimilhança pautada na realidade evocada pelo enunciador que se autobiografa.

De modo geral, portanto, o que pretendo demonstrar é que uma narrativa de cunho autobiográfico, cujo texto, via de regra, é escrito no tempo pretérito por um narrador em primeira pessoa, mostra ser capaz de dar ao leitor uma sensação de acabamento, de completude a respeito de uma personagem, pois, no romance, “[...] porque o número das orações é necessariamente limitado [...], as personagens adquirem um cunho definido e definitivo que a observação das pessoas reais, e mesmo o convívio com elas, dificilmente nos pode proporcionar a tal ponto" (ROSENFELD, 2011, p. 34). Entendida dessa forma, enfatizo, na escrita literária do gênero autobiográfico à luz dos autores citados, as peculiaridade características do discurso literário e excluo do horizonte a busca por uma "verdade" extraliterária, posto que o texto é a própria realidade. Esse ponto de vista é fundamental para a compreensão do que chamo de equivoco de memória, conceito ainda em gestação e que tem como base as ideias de perspectivismo ameríndio e de equívoco controlado que serão exploradas na seção seguinte.

\section{Perspectivismo, tradução e equívoco}

Tomarei a liberdade de fazer aqui uma breve incursão pelo mundo da antropologia a fim de discutir o pensamento de Eduardo Viveiros de Castro, responsável, juntamente com Tânia Stolze Lima, pelo desenvolvimento do conceito de perspectivismo ameríndio. A ideia teria surgido a partir de uma anedota contada por Lévi-Strauss, segundo a qual os 
espanhóis, durante a chamada conquista da América, enviavam às Antilhas comissões para saber se os povos nativos de lá possuíam alma, ao passo que os povos nativos, após capturarem e matarem os espanhóis, afundavam os cadáveres na água para saber se eles apodreceriam, ou seja, para descobrir se realmente possuíam um corpo. A história demonstra para os autores que "[...] os europeus nunca duvidaram de que os índios tivessem corpo (os animais também os têm); os índios nunca duvidaram de que os europeus tivessem alma (os animais e os espectros dos mortos também as têm)." (VIVEIROS DE CASTRO, 2018, p. 37). Grosso modo, está aí a gênese do perspectivismo, ou seja, para os povos ameríndios todos os seres (onças, plantas, porcos, humanos) possuem uma alma/espírito e se veem como pessoas, compartilhando assim de uma mesma cultura, mas a experienciando de modos diversos de acordo com as suas corporeidades. Por isso todos os seres

[...] veem seu alimento como alimento humano (os jaguares veem o sangue como cerveja de milho, os urubus veem os vermes da carne podre como peixe assado etc.), seus atributos corporais (pelagem, plumas, garras, bicos etc.) como adornos ou instrumentos culturais, seu sistema social como organizado do mesmo modo que as instituições humanas (com chefes, xamãs, festas, ritos...). (VIVEIROS DE CASTRO, 2018, p. 45)

No entanto, não há uma simultaneidade entre essas potencialidades. Uma onça se vê como pessoa diante de sua presa, mas essa mesma presa, quando assume o papel de predador diante de outro animal, verá esse animal como presa e a si mesma como pessoa. Todos os seres, portanto, possuem uma potencial perspectiva. Contudo, não é possível assumir uma outra perspectiva diferente da sua, sob pena de ter sua alma capturada. Assim, a onça e sua presa não podem, ao mesmo tempo, verem-se como pessoa. Apenas os xamãs possuem a habilidade de transitar entre diferentes perspectivas:

O xamanismo ameríndio pode ser definido como a habilidade manifesta por certos indivíduos de cruzar deliberadamente as barreiras corporais entre as espécies e adotar a perspectiva de subjetividades 'estrangeiras', de modo a administrar as relações entre estas e os humanos. (VIVEIROS DE CASTRO, 2018, p. 49) 
Se num princípio pré-cósmico os seres eram almas/espíritos todos possuem um fundo comum e radicalmente diferente de sua forma atual. O que o autor quer demonstrar é que há uma profunda diferença que marca os corpos de todos os seres. Todos são, no fundo, uma outra coisa diferente daquela que aparentam. Por isso a importância da corporeidade, visto que é a partir dela que os seres irão vivenciar a sua "pessoalidade". O mesmo tema do corpo, no que se refere à memória, é posto assim por Henri Bergson,

De fato, observo que a dimensão, a forma, a própria cor dos objetos exteriores se modificam conforme meu corpo se aproxima ou se afasta deles, que a força dos odores, a intensidade dos sons aumentam e diminuem com a distância, enfim, que essa própria distância representa sobretudo a medida na qual os corpos circundantes são assegurados, de algum modo, contra a ação imediata de meu corpo. [...] Os objetos que cercam meu corpo refletem a ação possível de meu corpo sobre eles. (1999, p. 15)

O que é confirmado por Viveiros de Castro:

Os animais veem da mesma forma que nós coisas diversas do que vemos porque seus corpos são diferentes dos nossos. [...] Não estou me referindo a diferenças fisiológicas [...], mas aos afetos que atravessam cada espécie de corpo, as afecções ou encontros de que ele é capaz [...]. (VIVEIROS DE CASTRO, 2018, p. 66)

Como se vê, o corpo e aquilo que o afeta desempenham um importante papel no modo como percebemos as coisas. E é esse mesmo corpo que irá depois narrar para os demais a sua experiência e a sua memória de determinada percepção. Nesta altura, ainda que meu estudo não busque verificar a presença do corpo que escreve, é importante dizer que não nego a sua existência, como bem lembra Michel Foucault (2009, p. 294) quando indagado sobre o tema em sua famosa conferência sobre a morte do autor: "Definir de que maneira se exerce essa função [autor], em que condições, em que campo etc., isso não significa, convenhamos, dizer que o autor não existe".

Ainda que de modo apressado, a exposição do que seria o perspectivismo ameríndio coloca em pauta um outro tema caro à antropologia e também à literatura: o da tradução. Como saída para o problema de como traduzir, em termos de nossa cosmologia, uma visão ameríndia, Viveiros de Castro propõe o conceito de "equivocidade controlada". O autor 
explica o termo recorrendo a outra narrativa, esta mais geral, sobre um homem europeu que, perdido na floresta, é encontrado e convidado por indígenas para tomar cerveja de mandioca. Ao chegar na aldeia os nativos lhe oferecem uma cuia com sangue humano. O que o antropólogo propõe é que, mesmo quando estão falando das mesmas coisas (a cerveja de mandioca) ambos não estão falando das mesmas coisas. Ao dizermos, na tradução, que o sangue humano está para os nativos daquela tribo, assim como a cerveja está para os nãonativos, estamos traduzindo com base em um equívoco controlado. E ele é controlado

[...] no sentido em que se pode dizer que andar é um cair continuamente para a frente de um modo controlado. [...] o equívoco aparece ali como o modo por excelência de comunicação entre diferentes posições perspectivas, e portanto como condição de possibilidade e limite da empresa antropológica. (VIVEIROS DE CASTRO, 2018, p. 87)

Assim, diferente do que a palavra sugere no seu uso rotineiro, o equívoco aqui deve ser entendido não como erro, mas como a condição mesma de comunicação entre duas perspectivas cosmológicas diferentes. Em outras palavras, a tradução por meio do equívoco pressupõe uma diferença que não permite que as duas perspectivas experienciadas por corpos diferentes, cada uma à sua maneira, a respeito de uma mesma bebida (conceito), se confundam. Usando um outro exemplo: o urubu, quando assume a sua forma de fundo bumana, vê-se a si mesmo como pessoa e vê os vermes de uma carcaça como sendo peixe grelhado. Nós, imbuídos de nossa perspectiva bumana a partir de nosso corpo/forma, veríamos apenas os vermes. Dando a palavra mais uma vez ao autor:

Os animais utilizam as mesmas "categorias" e "valores" que os humanos [...] Mas as coisas que veem, quando veem como nós vemos, são outras: o que para nós é sangue, para os jaguares é cerveja; o que para as almas dos mortos é um cadáver podre, para nós é mandioca fermentando; o que vemos como um barreiro lamacento, para os tapires é uma grande casa cerimonial, e assim por diante. (VIVEIROS DE CASTRO, 2018, p. 64)

Há, contudo, possibilidades de transição entre pontos de vista. Neste caso "Se um homem começa a ver os vermes que infestam uma carcaça animal como peixes grelhados, à maneira dos urubus [...] ele está gravemente doente [...]" (Ibidem, p. 63). 
Voltando ao início de meu texto, quando falei do conto de Borges, é possível ler as passagens do Quixote de Cervantes e de Pierre Menard da mesma maneira como o sangue/cerveja na anedota contada acima. Também no texto do escritor argentino estamos ao mesmo tempo falando das mesmas coisas e não falando das mesmas coisas. O Quixote de Pierre Menard é o mesmo que é outro. Ou seja, o mesmo texto, rememorado, no entanto é agora outro. O texto seria a alma (a mesma comum a cada leitor que, desavisado, presume ser o texto de Menard uma mera cópia de Cervantes), todavia, a perspectiva assumida por aquele que lê, pelo corpo/forma que lê - e pelo corpo/forma que escreve, por que não? é outra.

Saindo dessa incursão pelo mundo antropológico e pedindo desculpas pelas simplificações e generalizações cometidas, realizo aqui uma apropriação do conceito de equívoco controlado e proponho o conceito de equívoco de memória. Vejamos do que se trata.

No texto autobiográfico, caracterizado por um narrador que conta acontecimentos passados de sua vida, estamos, voltando ao senso comum, lidando com um acontecimento real, vivido, que jamais poderá ser retomado no tempo e no espaço, e com um outro acontecimento que procura retomar aquela experiência pregressa. Há, portanto, o que ocorreu, fato já inacessível, há o que lembramos e expressamos sobre o que ocorreu, e o resultado é uma terceira coisa que surge da diferença entre esses dois movimentos. A essa terceira coisa é que chamo equívoco de memória. Nesse caso, não interessa buscar uma comprovação testemunhal ou documental da memória enunciada, mas, sim, verificar o modo como no texto ocorre essa tradução do passado por meio do equívoco. E como analisar uma tradução sem compará-la com o "texto original”? Ora, como havia dito anteriormente, parto do princípio de que é não só infrutífero como já também recorrente em outras pesquisas essa tentativa, verdadeiro trabalho de Sísifo, de cotejamento entre os acontecimentos vividos por um autor e a narração desses acontecimentos em textos do gênero autobiográfico. O que sugiro a partir da perspectiva do equívoco de memória é a leitura do texto literário autobiográfico se concentre, antes, no resultado, já pressuposto, dessa tradução, buscando encontrar seus vestígios como evidências desse equívoco de memória, não no 
sentido de erro, como já dito, mas no de ser a própria, e única, possibilidade da tradução de um passado. Para tanto, é preciso reafirmar, com Viveiros de Castro, que

Traduzir é instalar-se no espaço do equívoco e habitá-lo. Não para desfazê-lo, o que suporia que ele nunca existiu, mas, muito ao contrário, para potencializá-lo, abrindo e alargando o espaço que se imaginava não existir entre as linguagens conceituais em contato - espaço que, precisamente, o equívoco ocultava. O equívoco não é o que impede a relação, mas aquilo que a funda e a propele: uma diferença de perspectiva. Traduzir é presumir que há desde sempre e para sempre um equívoco; é comunicar pela diferença, em vez de silenciar o Outro ao presumir uma univocidade originária e uma redundância última - uma semelhança essencial - entre o que ele e nós “estávamos dizendo". (VIVEIROS DE CASTRO, 2018, p. 91)

Desse modo, e lembrando o que já foi discutido na seção anterior, a escrita literária não deve ser compreendida como morte, mas como algo que opera fora desse dualismo morte/vida, como uma perspectiva, um modo de se "ver/ser memória", e assim sendo traduzir o vivido e/ou imaginado por meio do equívoco de memória, a fim de exacerbar no texto literário autobiográfico as diferenças entre algo que se quer apreender e a própria forma textual de sua tentativa de apreensão, diga-se tradução. Na seção seguinte procuro demonstrar de que modo esse conceito pode ser funcionar na análise literária tomando como exemplo um trecho do livro Infância, de Graciliano Ramos.

\section{Um esboço de análise}

Publicado em 1945, Infância narra as memórias de Graciliano Ramos dos três aos quatorze anos de idade, período que abrange as suas primeiras impressões do mundo, a relação com os pais e o difícil período de alfabetização até que lhe surgisse o gosto pela leitura e a escrita. Como já havia sinalizado anteriormente, a análise se dará com base no texto escrito pelo narrador, visto que assumo uma já impossibilidade de identidade entre este e a pessoa física de Graciliano Ramos. Desse modo, é possível ver, já na frase que inaugura a obra, um exemplo daquilo que chamo de equívoco de memória:

A primeira coisa que guardei na memória foi um vaso de louça vidrada, cheio de pitombas, escondidas atrás de uma porta. Ignoro 
onde o vi, quando o vi, e se uma parte do caso remoto não desaguasse noutro posterior, julgá-lo-ia sonho. Talvez nem me recorde bem do vaso: é possível que a imagem, brilhante e esguia, permaneça por eu a ter comunicado a pessoas que a confirmaram. Assim, não conservo a lembrança de uma alfaia esquisita, mas a reprodução dela, corroborada por indivíduos que lhe fixaram o conteúdo e a forma. De qualquer modo a aparição deve ter sido real. (RAMOS, 1977, p. 9, grifo meu)

Os trechos grifados destacam alguns elementos textuais importantes, sendo o primeiro deles a afirmação guardado na memória, expressão que representa a ideia recorrente da memória vista como uma espécie de reservatório. A esse respeito Nascimento dirá que

Uma das consequências das investigações freudianas foi a de subtrair a memória do conceito tradicional que a pensaria como um simples "reservatório", onde se depositariam conteúdos substantivos, os quais de modo mais ou menos regular retornariam à consciência. (1999, p. 168)

O mesmo autor irá fazer, a partir de Derrida, uma conexão com Friedrich Nietzsche para afirmar que a memória seria não uma repetição, ora mais, ora menos fiel, mas um resultado de interpretações que ocorrem de acordo com as forças heterogêneas que dão sentido ao que vivemos. Admitindo isso, o narrador da obra parece ainda estar trabalhando com a tese da memória como um repositório em que ele pode guardar algo, e, consequentemente, procurar ou retirar esse algo de lá mais tarde.

Outra imagem criada pelo texto é o da memória como um rio que conecta imagens e que as faz desaguar umas nas outras. Para o narrador, não fosse assim, aquilo que lembra poderia não passar de sonho. Interessante pensar nessa afirmação e tomar o sonho, diferente do sentido comumente atribuído à palavra, não como algo oposto ao real, mas como também um componente de certa experiência. Se o corpo possui, como em Bergson (1999) e depois Viveiros de Castro (2018), uma importância fundamental no modo como percebemos o mundo, o sonho não pode ser tido como algo que esteja fora dessa possibilidade de experiência. Vimos com Antonio Candido (2011) que não há ser humano que possa passar um dia inteiro sem sonhar, sem ficcionar. Portanto o sonho é também um elemento que gera experiência e não um símbolo de algo irreal, como posto pelo narrador. 
Na sequência do texto lê-se a palavra recordar, vocábulo já citado na primeira seção deste texto no breve comentário que fiz a respeito dos contos de Borges. Para confirmar a recordação, para acreditar que a imagem que lhe vem à mente não é apenas resultado de um sonbo, o narrador recorre a pessoas que confirmam a sua memória. É possível conectar esse último trecho à fala de Maurice Halbwachs (1990, p. 25), para quem, sobre um evento ou situação, "[...] a primeira testemunha, à qual podemos sempre apelar, é a nós próprios". À primeira vista essa declaração pode sugerir algo como um solipsismo, no entanto a memória, na concepção desse autor, será sempre um jogo entre individualidade e coletividade. Em seu livro A memória social (1990), ele mostra de que modo nossas recordações são afetadas pelos grupos sociais aos quais pertencemos e com os quais nos relacionamos. Por isso, para ele

[...] nossas lembranças permanecem coletivas, e elas nos são lembradas pelos outros, mesmo que se trate de acontecimentos nos quais só nós estivemos envolvidos, e com objetos que só nós vimos. É porque, em realidade, nunca estamos sós. (HALWBACHS, 1990, p. 26)

Como se vê, as lembranças são construídas pela personagem por meio das experiências e das memórias também de uma coletividade, embora esta não seja a garantia de que tal cena tenha realmente existido, o que se confirma em deve ter sido real. Essa última frase forma com as anteriores um conjunto que ajuda a compreender o equívoco de memória, conceito que aqui procuro desenvolver, pois é possível identificar nelas traços, vestígios da tradução que o narrador procura realizar, o que confirma e exacerba essa profunda diferença entre um passado vivido e a sua enunciação no presente do texto.

Um pouco mais à frente o narrador de Infância diz, na tentativa de lembrar de um uma cena em que a mãe lê um romance em voz alta,

De um deles ressurgem vagas expressões: tributo, papa-rato, maluquices que vêm, fogem, tornam a voltar. Tento arredá-las, pensar no açude, nos mergulhões, nas cantigas de José Baía, mas os disparates me perseguem. Lentamente adquirem sentido e uma historieta se esboça: 
Papa quê? Julgo a princípio que se trata de papa-figo, vejo que me engano, lembro-me de papa-rato e finalmente de papa-bóstia. É papahóstia, sem dúvida:

Acorde, seu Papa-bóstia,

Nos braços de... (RAMOS, 1976, p. 17 grifo meu)

Novamente chamo a atenção para as partes destacadas, começando pelo adjetivo dado às memórias, elas são vagas. Em seguida o narrador utiliza verbos que jogam com a espacialidade. As lembranças parecem se deslocar, elas vêm, fogem, voltam, para depois lentamente, afinal, fazer sentido. Outro traço importante é o fato de que se trata de uma memória evocada pela oralidade, visto que o narrador busca, nesse episódio, lembrar/traduzir a voz de sua mãe.

Há na obra outros exemplos e a análise que propus aqui se constitui como uma espécie de esboço que procura demonstrar esse conceito ainda em gestação e que se inscreve naquilo que Roland Barthes assim descreve.

Há uma idade em que se ensina o que se sabe; mas vem em seguida outra, em que se ensina o que não se sabe: isso se chama pesquisar. Vem talvez agora a idade de uma outra experiência, a de desaprender, de deixar trabalhar o remanejamento imprevisível que o esquecimento impõe à sedimentação dos saberes, das culturas, das crenças que atravessamos. (2013, p. 49).

É a partir dessa compreensão, e considerando a necessidade de discussão e aperfeiçoamento do conceito de equívoco de memória, que propus a escrita deste artigo, no qual tomo as relações entre literatura e memória tendo como pressuposto a ideia de que a obra literária em si deve ser tomada como realidade e como criadora também de realidades. A ficção como componente do mundo real. E se em alguns momentos valho-me aqui das dicotomias realidade/ficção e autor real/narrador o faço também como um equívoco de tradução, assim como Lúcia Sá, no livro Literaturas da floresta (2012), precisa se referir aos termos bom e mau para dizer que estes dois conceitos se confundem na cosmologia ameríndia, afinal somos todos, no fundo, uma outra coisa radicalmente diferente de nós mesmos. 


\section{EQUIVOCATION POSSIBILITIES: THE TRANSLATION OF PAST IN THE AUTOBIOGRAPHICAL TEXT}

ABSTRACT: Based on the concepts of Amerindian perspectivism and Controlled Equivocation (VIVEIROS DE CASTRO, 2018), this article aims at presenting the thesis that in the literary autobiographical writing there is a translation by memory equivocation. Therefore, there is what occurred, there is what is enunciated about that, and the result is a thing that emerges from the difference between these two movements: memory equivocation. Based on this idea and taking literature and fiction as elements that compose the reality (CANDIDO, 2011, 2006; HALL, 2003, BAKHTIN, 2011), the text the discusses the interlacing between literary language and memory (LE BRETON, 2009; HALBWACHS, 1990) in order to present the basis to the development of memory equivocation, a concept in built.

KEYWORDS: Autobiography; Literature; Memory.

\section{REFERÊNCIAS}

ARFUCH, Leonor. O espaço biográfico: dilemas da subjetividade contemporânea. Tradução de Paloma Vidal. Rio de Janeiro: EdUERJ, 2010.

BAKHTIN, Mikhail. Estética da criação verbal. Tradução de Paulo Bezerra. 6. ed. São Paulo: WMF Martins Fontes, 2011.

BARROS, Mariana Luz Pessoa de. A arquitetura das memórias: um estudo do tempo no discurso autobiográfico. 2006. 233 f. Dissertação (Mestrado - Programa de Pós-Graduação em Linguística) - Universidade de São Paulo, São Paulo, 2006.

BARTHES, Roland. Aula: aula inaugural da cadeira de semiologia literária do Colégio de França, pronunciada no dia 7 de janeiro de 1977. Tradução de Leyla Perrone-Moisés. São Paulo: Cultrix, 2013.

BENJAMIN, Walter. Sobre o conceito de história. In: Obras escolbidas, V.1: Magia e técnica, arte e política: ensaios sobre literatura e história da cultura. Tradução de Sérgio Paulo Rouanet. 3. ed. São Paulo: Brasiliense, 1987. p. 222-232.

BERGSON, Henri. Matéria e memória: ensaio sobre a relação do corpo com o espírito. Tradução de Paulo Neves. 2. ed. São Paulo: Martins Fontes, 1999.

BORGES, Jorge Luis. Fiç̧̃es. Tradução de Carlos Nejar. 2 ed. Porto Alegre: Editora Globo, 1976.

CANDIDO, Antonio. Direito à literatura. In: . Vários escritos. Rio de Janeiro: Ouro sobre azul, 2011. p. $171-193$.

. A literatura e vida social. In: Literatura e sociedade. Rio de Janeiro: 
Ouro sobre Azul, 2006. p. 27-49.

CARVALHEIRO, Karine. Autobiografia e memória de Gabriel García Márquez: ficcionalização de si. 2017. 91 f. Dissertação (Mestrado - Programa de Pós-Graduação em Letras,) - Universidade Estadual do Oeste do Paraná, Cascavel, 2017.

CORRÊA, Maria de Nazaré Fonseca. Literatura, história e memória: uma leitura da poesia de Mario Benedetti. 2013. 183 f. Dissertação (Mestrado em Literatura) - Universidade de Brasília, Brasília, 2013.

DURÃO, Fábio Akcelrud; TINTI, Tauan. Sobre a memória na sociedade da imagem. In: CECHINEL, André; MUELLER, Rafael Rodrigo. Formação bumana na sociedade do espetáculo. Chapecó, SC: Argos; Criciúma, SC: Ediunesc, 2019. p. 257 - 280.

FOUCAULT, Michel. O que é um Autor? In: . Ditos e escritos. Estética: literatura e pintura, música e cinema. MOTTA, Manoel Barros da (Org.). Tradução de Inês Autran Dourado Barbosa. 2. ed. Rio de Janeiro: Forense Universitária, 2009. p. 264-298

HALBWACHS, Maurice. A memória coletiva. Tradução de Laurent Léon Schaffter. São Paulo: Vértice; Editora Revista dos Tribunais, 1990.

HALL, Stuart. Significação, representação, ideologia: Althusser e os debates pós-estruturalistas. In: SOVIK, Liv (Org.). Da diáspora: Identidades e mediações culturais. Tradução de Liv Sovik. Belo Horizonte: Editora UFMG, 2003. p. 160-198

LE BRETON, David. As paixões ordinárias: antropologia das emoções. Tradução de Luís Alberto Salton Peretti. Petrópolis, RJ: Vozes, 2009.

LIMA, Denise Noronha. O espaço da memória em José Saramago: literatura e autobiografia. 2017. 392 f. Tese (Doutorado - Programa de Pós-Graduação em Letras) - Universidade Federal do Ceará, Fortaleza, 2017.

NASCIMENTO, Evando. Derrida e a literatura: "notas" de literatura e filosofia nos textos de desconstrução. Niterói, RJ: EdUFF, 1999.

PLATÃO. Diálogos: Mênon, Banquete, Fedro. Tradução de Jorge Paleikat. Rio de Janeiro: Ediouro, s/d.

POSSEBOM, Rute Augusto. Infância, de Graciliano Ramos: memória ou autobiografia. 2011. 112 f. Dissertação (Mestrado - Programa de Pós-Graduação em Literatura e Crítica Literária) - Pontifícia Universidade Católica de São Paulo, São Paulo, 2011.

RAMOS, Graciliano. Infância. 12. ed. Rio de Janeiro: Record, 1977.

RICOEUR, Paul. A memória, a bistória, o esquecimento. Tradução de Alain François et al. Campinas, SP: Editora da Unicamp, 2007.

ROSENFELD, Anatol. Literatura e personagem. In: CANDIDO, Antonio et al. A personagem de ficção. São Paulo: Perspectiva, 2014. p. 9-49. 
SÁ, Lúcia. Literaturas da floresta: textos amazônicos e cultura latino-americana. Rio de Janeiro: EdUERJ, 2012.

VIVEIROS DE CASTRO, Eduardo. Metafísicas Canibais: Elementos para uma antropologia pós-estrutural. São Paulo: Ubu Editora, 2018.

Recebido em: 31/02/2020.

Aprovado em: 15/10/2020. 